\title{
CELEBRATING SHARIA INDONESIA: ISLAMIC HARMONY AND PANCASILA IN THE VISION OF INDONESIAN NATIONALITY
}

\author{
Lufaefi \\ Postgraduate Program, Institut Perguruan Tinggi Ilmu Al-Qur'an (PTIQ) \\ Jakarta, Jl. Batan I. No.63, RT.2/RW.2, Lb. Bulus, Kec. Cilandak, Jakarta \\ Selatan, Daerah Khusus Ibu Kota Jakarta, Indonesia, 12440 \\ Email: lufaefi2@gmail.com
}

\begin{abstract}
This article discusses and offers at the same time the issue of formalizing Islamic law in Indonesia. It started with a debate about the ideals of the formalization of Islamic law, which never ended. The debate about this has led to at least two significant views, namely fundamentalism and secularism. The first group believes that Islam is a religion that prepares solutions to all problems. In the context of Indonesians, such rules override local state laws, such as the 1945 Constitution and the Pancasila ideology. Meanwhile, the second group tried to give up religion in answering modern problems. This article uses a qualitative method, and two knives of analysis, namely socio-historical and maqāsid of the Koran. This paper proves that the ideology of the State of Indonesia, namely Pancasila, contains substantive sharia values. The values of Islamic law are contained in every principle and are following the vision of Indonesian nationhood as a nation that harmonizes between Islam and nationality. These values are relevant to the values that exist in the country of Medina as the first country formed by the Prophet Muhammad. With the values of Islamic law in the Pancasila, Indonesia is worth mentioning as a sharia country.
\end{abstract}

Keywords:Sharia Indonesia; Fundamentalism; Secularism; Pancasila; Islamic Sharia

How to Cite: Lufaefi, L. (2019). Celebrating Sharia Indonesia: Islamic Harmony and Pancasila in The Vision of Indonesian Nationality. Jurnal Ilmiah Al-Syir'ah, 17(2), 106-120. Permalink/DOI: http://dx.doi.org/10.30984/jis.v17i2. 951

Copyright $@$ 2019, Jurnal Ilmiah Al-Syir'ah

Celebrating Sharia Indonesia: Islamic Harmony and Pancasila in The Vision of Indonesian Nationality

Lufaefi 


\section{INTRODUCTION}

The tug of war of formalizing Islamic law in the public sphere is a latent topic that does not end in the vortex of the global world, including in Indonesia. The ideals of implementing Shari'ah in total are not only individual demands in the realm of ritual worship, but also become public demands in the realm of social and state administration (Burhanuddin, 2016). The emergence of Islamic Banks, hijab shar'i, ruqyah shar'iyyah shar'i tourism, and other symbolic things that are literal are part of the real evidence of the best-selling syariah market in the community. Coupled with the encouragement of some Islamic groups who aspire to formalize Islamic Sharia in all lines of life, making the Shari'a label increasingly desirable to be applied in all segments of life, both in the realm of economic, social, political, cultural, even in the state law segment (Yunus, 2015). The Shari'a label is the ideal and foundation of most modern Muslim societies and is a means of legitimacy that a person has genuinely embraced religion.

According to Komaruddin Hidayat, the increasing meaning, as well as the ideals of formalizing Islamic law as a whole in Indonesia, are not balance with a holistic-comprehensive understanding of religion. Islamic law led to the meaning of the Shari'a, which was stopping in the symbolic, fiarfiyyah, and textual areas and often overriding its essence. As a result, the object of the Shari'a is only interpreting as the law that is recorded in the text of religious sources, in this case, the text of the Koran (and the text of the Sunnah). While in addition to the sources written in the text of the Koran verse is considered not Shari'a, it is even considered a religious threat and is accused of being a product of heresy which only mislead the faith of humanity, both in the world and the hereafter (Hidayat, 2017). Whereas in fact, including the applicable Shari'a in the Islamic world is Shari'a that was not born from the text of the Koran, such as istiḥsān, istihssab, syar'uman qablana, and so forth.

The religious phenomenon as mentioned above, which later gave birth to symbolic interpretation of the symbolic sharia, also raises even more complex problems, namely the perceived laws and essential state that were imposed in Indonesia, such as the ideology of the Pancasila and the 1945 Constitution, as products of kufr, which are incompatible with the Shari'ah that has outlined God in the Qur'an or Hadith (Haq, 2013). According to Hamka Haq, the absence of the 1945 Constitution and Pancasila in religious sources explicitly makes both considered as laws and ideologies that are contrary to the Shari'a of God (Haq, 2013). Sharia is only interpreted symbolically, without the essence and universal values. So anything that is outwardly incompatible with Islamic law must be dismissed/prohibited.

In the end, the Unitary State of the Republic of Indonesia (NKRI) with the concept of nation-state was considered by the Sharia formalism movement as a secular state, far from the laws of the Shari'a of God (Hiariej, 2010). Shari'a is what is known as the formalistic symbolic movement in viewing religion. In fact, according to Denny, the interpretation of Islamic sharia which is limited to the textual and symbolic domain in the Indonesian context, will have significant implications for the 
idea of replacing the concept of the NKRI (nation-state) with a Shariahcompliant NKRI that has not yet concrete parameters and examples (Denny JA, 2019). So according to the movement (sharia formalism), Indonesia is required to formalize Islamic law in all lines of life in order to be free from bid'ah.

The next implication is the rise of radical-fundamentalist movements that aspire to replace the unitary state system - and its ideology and law - by using the Islamic Shari'a system (khilāfah islāmiyyah). It was also confirmed by An-Nafi, that in order to realize the application of Islamic law in a whole in the private and public sphere, an Islamic group was born based on Islamic law to replace the kufr system that is not stipulating in the Koran and Hadith (An-Nafi, 2016). Rodin, in a study, mentioned that some of these groups include the Indonesian Mujahidin Council (MMI), Hizb utTahrir Indonesia (HTI), Laskar Jihad, and the Islamic Defenders Front (FPI) (Rodin, 2019).

Emna Laisa in her research emphasized that understanding religion as a form of purification of Islam and the total application of the symbolic Islamic Shari'a system in the public sphere will give birth to radical understandings which in the end is the emergence of radical movements and even terrorism that can threaten the security and integrity of a country, even the world. Thus it was motivated by the spirit of Islamization globally, where Islamic Shari'ah was predicted to be solutive in fixing all the problems of human life - whatever - which they said was due to the further alienation of God's human laws (Laisa, 2016). On this basis, this paper was conceived, namely, in the framework of observing the meaning of Islamic law in the space of the Indonesian nation-state.

\section{RESEARCH METHODS}

This research is library research (library research) whose process is by collecting book data and other readings related to Islamic Sharia and its formulations and related matters, to then be processed into valid data and narrated with words objectively (Zed, 2004). Besides, this study uses a socio-historical approach whose purpose is to read the Islamic Shari'a with its relation when applied in different spaces and times (Susanto, 2006). Furthermore, this study also uses the method of interpretation of maqāșidī whose purpose is to read and ensure that Islamic sharia is implementing in the social and public realm following the objectives of the establishment of Islamic law itself, such as justice and benefit for all humanity ('Ashur, 1997). All data collected is edited, combined, extracted, and narrated in a language that can be understood by the reader.

\section{RESULTS AND DISCUSSION}

The term religious state emerges as a derivative of the problem of applying Islamic Shari'ah totally in the public sphere. Within the historical scope, this issue arose, starting in interpreting the State of Medina, which was the first country in the history of the Islamic world led directly by the

Celebrating Sharia Indonesia: Islamic Harmony and Pancasila in The Vision of Indonesian Nationality 
Prophet Muhammad. As a justification for the obligation to implement Islamic law, the Medina state is said to be the first Islamic state because it was directly led by the Prophet Muhammad, who was the recipient of revelations from God. He cannot use Islam in running the state institution of Medina (Fakhruddin, 2011). Although, according to Hamka Haq, the essence of an Islamic state is not an Islamic state with the adoption of symbolic-formalistic sharia, (an Islamic state) is a country with Islamic values whose goal is to create justice and mutual benefit (Haq, 2013). In a sense, Islam prioritizes universal values rather than prioritizing textualsymbolic which cannot provide full benefit.

The bearers of the ideals of formalizing Islamic Sharia believe that the caliphate is also a continuation of the Islamic state modeled by four caliphs, namely Abu Bakr As-iddiddq RA, Umar Ibn Khattāa RA, 'Uțman' Ibn 'Affān RA and 'Alī Ibn Ab̄i TTālib RA The leadership of these companions was considered to be the leader of a religious state because all of them were the heirs of the Prophet in terms of leadership and scholarship, where they met face to face and studied directly with the Messenger of Allah as the bearer of the message of Islam. After the four caliphs mentioned above completed the reins of power, the bearer continued by the caliphs of the Umayyads and 'Abbasids. The post-Khalifah authorities are also considered leaders of Islamic countries because they based on Islamic Sharia laws (Fitriono \& Suhono, 2017). For the bearers of the religious state, the leadership that began from the Prophet Muhammad until the four caliphs after that and continued by the dynasties after that is a real proof of the existence of the Islamic state model as the first model in Islam. So there is no reason to continue the caliph's mission in modern times.

The ideals of formalizing Islamic law continue to echo all the time. In the context of Indonesians, the idea of formalizing Islamic law has even emerged since shortly after the Indonesian nation declared its independence, and continued until the reform era. Indonesian independence could see from the necessary formulation process of the Republic of Indonesia, up to the Old Order era. Although in the New Order era, this issue was not so much in the spotlight, shortly after its fall (the New Order era), this issue re-emerged to the public. The logic of the majority (Muslims) has always been a pretext for groups that advocate the formalization of Sharia to encourage the application of formal Islamic law. (Ruslan, 2013). However, it became the fact that Indonesian independence was not only fought for by Muslims. So even the demand for the formalization of the Shari'a has considerable consequences. In addition to the consequences of political, historical, sociological, and anthropological factors, the future of the Indonesian nation is at stake for anyone who wants to formalize the Shari'a to replace the law and ideology that has been rooted in the body of the nation for a long time (Effendy, 2000)

Some groups that have a fundamental view and aspire to formalize Sharia in Indonesia include JI (Jama'ah Islamiyah), MMI (Indonesian Mujahidin Council), HTI (Hizb ut-Tahrir Indonesia), Salafi Wahabi, FPI (Islamic Defenders Front), Laskar Jihad Ahlussunnah Waljama'ah, and KISDI (Islamic Committee for World Solidarity) (Asrori, 2015). All of 
these groups have the same vision, namely to formalize the Islamic Shari'a in the life of the nation and state in total, although there are typological differences between one another (Kafid, 2015), especially in terms of characteristics, thoughts, and movements (Zada, 2002).

Indonesian Mujahidin Council (MMI) has its characteristics in the formalization mission of the Shari'a. This group does not have an agenda to revolutionize existing laws and systems, but to make democracy as a tool to win the struggle for the formalization of Islamic law in the form of a religious state (Mustofa, 2012). While HTI has a view of total Islamization, Islam must be applied as a whole, regardless of democracy. HTI wants to abolish the democratic system and replace it with an Islamic legal system (An-Nabhani, 2002). The HTI mission has similarities with Salafi groups regarding the purification of Islam in all aspects of Indonesian life. For this group, bid' ah is a practice that must be removed from the lives of Muslims because it did not exist in the time of the Prophet. Unlike HTI, Salafi groups do not play on the map of state politics. This kind of group movement, in the post-reform era, was not only carried out at the national level but also penetrated the local realm by bringing up the issue of Sharia Laws (Kafid, 2016).

The birth of Islamic fundamentalism in Indonesia cannot separate from the collaboration between Indonesia and the Middle East, one of which is Egypt and the Arabs. The number of students who were inspired by the thoughts of Sayyid Qutub, Jamaluddin Al-Afghāni, Taqiy Al-Din AnNabhāni was a form of collaboration in the field of education between Indonesia and these countries which was outlining in Indonesia (Tibbi, 2016). This model group has the characteristics, among others, the view that the implementation of Islamic teachings must be the same as the times of the Prophet, and Islam must be free from the things of heresy. Traditions that did not exist in the time of the Prophet must destroy. As a result, this mindset raises religious understandings that are static, rigid, ahistorical, and party-biased (Haq, 2013). The Islamization of law and the system in the Indonesian state was concluding by fundamentalists (Mansurnoor, 2009).

The opinion, these groups release tolerance values at the level of human and national relations. Because consciously or not, formalizing Islamic conditions is the same as not considering the role of other citizens (non-Muslims) who, whereas - in the context of Indonesia - have an essential role in the upholding of the Indonesian state (Kafid, 2015). Meanwhile, according to Zuhdi, the interpretation of symbolic Islamic sharia in various country contexts can lead to hostility and division (Zuhdi, 2012). Islamic sharia has implications for the disruption of unity in diversity in the context of Indonesia as a multicultural nation.

\section{SHARIA LAW IN THE VACUUM}

Sharia regulations are regulations made by the Governor in cooperation with the Regional Representative Council (DPRD) of the Regency or by the Mayor in collaboration with the Regional Representative Council (DPRD) of the City. According to Yusril Ihza Mahendra, an expert

Celebrating Sharia Indonesia: Islamic Harmony and Pancasila in The Vision of Indonesian Nationality 
on state law, the naming of sharia regulations is non-existent. Because according to him, if examined academically, naming is challenging to achieve in the real world; it is because of the scope of the Shari'a. In terms of sharia law implications for the chaos of meaning (Mahendra, 2019).

More than the meaning above, Islamic groups who aspire to formalize Islamic law consider that Islamic law, as stated in the text of the Qur'an and Sunnah, must apply in state laws. Using rules made by humans or interfering with them is certainly not a sharia rule, and using it is tantamount to using the law of taghut and kufr (Khalid, t.th). The implication, all forms of law made from outside the Qur'an, such as ijtihad, qiyās, istiḥsān. Are considered as not Islamic law. Consequently, classified as taghut and kufr laws are also constitutional laws that are human-made products.

However, it is not like the above. Islamic Sharia, which developed from the past until now, is inseparable from the results of human ijtihad (ulama). Islamic Sharia is not only in the form of law that is written explicitly in the manuscript of the Koran but also licensed products because they consider the time and place, even if they have to 'depart from the Qur'an' (Bultajiy, 1970). The interpretation of Shari'a by stopping the Qur'anic text and the Sunnah text will have fatal consequences because the language and sociological context 14 centuries ago when the revelation revealed with the present are not the same (Junaidi, 2003). The meaning of sharia does not stop at the historical meaning which cannot develop. Sharia will continue to change according to the context in which humans are facing.

It should emphasize here that in its historical side, many laws exist in the verses but are not applying by people who have competent religious authority. In the reign of 'Umar Ibn Kha misalnyaāb, for example, he had undertaken the intention of not giving State property to people who had just converted to Islam (muallafah qulübuhum), even though the rules for giving compensation to people who just entered Islam were write in the QS. AtTaubah: 60. According to Umar, the verse applies when those who convert to Islam need to be respected and are still weak. If not, then the use of state money for a greater interest is essential than just giving it to a handful of financially well-established people (Bultajiy, 1970). In short, Umar made the law by starting from a law written in the Qur'anic text.

Other evidence is also what was done by Umar after winning the conquest of Iraq and Syria, where he did not give war booty to his soldiers because the state's needs were no more urgent even though the written rules regarding the distribution of booty in war clear contained in the Koran, namely in the QS. Al-Hasyr: 6-10. However, again, Umar departed from the Qur'an because it was considered a law that was no longer relevant. Where warriors at that time consisted of rich people, and the needs of the state must also prioritize for its progress (Bultajiy, 1970).

The idea of Islamic law in the public sphere seems to still create ambiguity in conceptuality. There are still inconsistencies here and there. 
Islamic Sharia not only consists of laws written in the Qur'an and Sunnah texts but also includes the results of ijtihad aimed at the benefit and broader good of the people. Complementing the meaning of Islamic law is only for the benefit of a group of people based on the text of the Qur'an and Hadith, leaving aside the meaning of Islamic law from other sources is a conclusion that is too hasty and should shun.

\section{SHARIA IS NOT ISLAM, ISLAM IS NOT SHARIA}

Islam is not parallel with Shari'a. Likewise, Sharia is not equivalent to Islam. Citing the opinion of Mustafa Al-Maraghi, Islam is a religion whose adherents are required to worship Allah (not shirk) and instill faith in every deed of his actions wherever and whenever (Al-Maragghi, 2010). While the Shari'a is the path taken by humans - whatever their religion - to reach salvation. Every Prophet, who was delegated by Allah to deliver the message of God, has a different Shari'a. The Shari'ah of Prophet Idris, for example, is a religion, and the religion meant is faith in Allah and consistent. While the Shari'a prophet Musa is the truth, which puts goodness away from the prohibition.

Furthermore, the Shari'a of Prophet Jesus is compassion. Moreover, the Shari'ah of the Prophet Muhammad SAW is a mercy for all nature (AlșAsmawi, 2004). Every religion has a different form of Shari'a from one another and should not generalize into one form of Islamic Sharia.

Based on the discussion above, Islam is more specific but not exclusive. While the Shari'a is broad and universal, if quoting Imam AlGhazali's ideas as quoted by Lufaefi, a law can be said as a shari'ah when it can teste with five principles, namely to guard the soul (hifz an-nafs), safeguard religion (hifz ad-din), safeguard property (hifz al- $m \bar{a} l$ ), guarding 'reason (hifz al-'aql) and guarding offspring (hifz an-nașl) (Lufaefi, 2019). If a law can be seen from the five principles above and is still in the corridor of one of these principles, then it is certain that the practice of law is following the Shari'a, or even the Shari'a itself. On the other hand, a law which, although at a glance seems Islamic, if it cannot be in harmony with the five principles as what Al-Ghazali outlines, is challenging to say as Islamic Sharia law.

The opinion, in the context of Indonesians, the essence of Islamic law has been neatly woven into the public sphere, although not in the same sense as the Qur'anic or symbolic texts (Denny, 2019). As a Muslim, it is a fortune to be able to live in Indonesia. Muslims are free to practice worship anywhere. They can pray at the Mall, in the recreation area, even on the road, however. They may also make the call to prayer at night, which is likely, a time of rest for non-Muslim citizens, its contrast to Muslim citizens of other countries, which can be captured by the authorities when praying in public places, such as when praying at the Eiffel Tower, France (Denny, 2019). Diverse Islam in Indonesia has the opportunity to apply the model of all worship without limitation, let alone regulated by the state in full. 
Religious people who live in the country of Indonesia, although diverse in terms of diversity, but the will as a large Muslim is always fulfilling, as long as it does not threaten unity. Indonesia has a Ministry of Religion, a ministry that will never be found in other countries in the world (Aritonang, 2004). In schools, Islamic education is teaching, both Islamicor public based schools. The state governs the pilgrimage, anyone - whether rich or poor - can save money to go to Baitullah. When Muslims fast, the stalls are closed by using curtains, even though many non-Muslim residents in the country have the right to eat during the day of the fasting month. However, non-Muslims have never protested. In the case of zakat, Muslims are organized by the State with the formation of Lazis so that Muslims can regulate zakat by managing the government (Fauzia, 2013). Although the diversity of religions exists in it, the needs in matters of Islamic religion always take precedence.

How Muslims should grateful to live in Indonesia. On Islamic holidays, the country takes the day off work routines by making a red date on each historic day of the Muslims, such as the Birthday of the Prophet Muhammad, Isra Mi'raj, the New Year of Hijrah. And not long ago, the government inaugurated National Santri Day (HSN) as a historic day of the struggle of Muslims against the Dutch-Indies Civiele Administration (NICA) invaders in Surabaya (Tamin, 2017).

The state also invited Muslims not always to use Conventional Banks to avoid usury, and invited to make Islamic Banks (Sabir, Ali and Habbe, 201280). Although in practice, it has not maximized, Muslims continue to improve it. And not long ago, the elected Vice President 20192024 was a cleric, National Islamic figure, who used to be the MUI. What a show of luck for Muslims in Indonesia.

Also, the government opened extensive permission for the establishment of Islamic Community Organizations in Indonesia. Even so, the formation of Islamic parties, such as the Prosperous Justice Party (PKS), the United Development Party (PPP), and Crescent Star Party (PBB) (Romli, 2004). The state is opening as many faucets as possible for Muslims to express themselves while not threatening unity. The state even "breeds" Muslims by praying using the teachings of Islam at every significant event, and inviting members of other religions to pray for themselves according to their own beliefs.

\section{LOOKING AT THE FUTURE OF SHARIA STATE IDEAS}

Discussing the future of the idea of a sharia state in the context of Indonesians is interesting to read what was written by Denny JA in writing, which then gave rise to many comments from various groups. In the article entitled NKRI Bersyariah or Humanized Public Spaces, Denny sharply criticized the idea of NKRI Sharia, which was echoed by the Islamic Defenders Front (FPI). There are two essential things to be revealed from Denny's writings. First, the idea of a Shariah-compliant NKRI that was launched by FPI is still absurd because there is no measurable parameter related to the meaning of sharia in the sequence of the 'Shariah NKRI.' 
According to Denny, there must be testing of the intended meaning of sharia, which then translates into valid data. Second, measure the data by comparing it with world countries that have implemented sharia. These two things have not been done by FPI when echoing the idea of a Sharia NKRI (Denny JA, 2019). For Denny, the concept of NKRI Sharia, which has been initiated by FPI, is still ambiguous in terms of methodology.

Another exciting thing from Denny's writings is when telling the results of research conclusions from the Islamic Index Institute, which consists of doctors who graduated from the Qur'an, economics and IT experts. The institute examines to reveal which countries in the world have Islamic values. The results of his research are very striking; it said that countries with high Islamic values come from countries that do not implement Islamic law in the public sphere, such as New Zealand, the Netherlands, Sweden, Ireland, Switzerland, Denmark, Canada, and Australia. While the countries with low Islamic values are the majority of Muslim countries, such as Malaysia, the United Arab Emirates, Indonesia and Saudi Arabia (Denny JA, 2019), this conclusion illustrates that the Shari'a does not necessarily change a person to be a Muslim correctly and adequately. Islamic values cannot be measured only by syllabic expressions and jargon with unclear parameters and no concrete examples.

More than that, Abdullah Ahmad An-Na'im, in one of his researches, stated that ideals to formalize Islamic textualist-historical sharia would find a considerable barrier. Changes in socio-historical settings require humans to look for alternative laws, even though they originate from ijtihad on written sharia law. In fact, according to An-Na'im, these ideals, in addition to finding difficulties, will also only lead to radical actions that oppose the locality law that already exists first (An-Na'im, 2016). An-Nu'ami strongly rejects the mainstreaming of the textual-historical Shari'a. Because according to him, the 14th-century sharia, when the Koran came down with the current sharia, has different situations and conditions of society that it faces. So it is not feasible to apply all the Shari'a to be the same as the Shari'a that is enforced in modern times now.

Starting with the ideals of formalizing the historical textualist Islamic Sharia, movements emerged that acted using terror. Citing data from the National Counterterrorism Agency (BNPT), incidents of suicide bombing and destruction of places of worship, such as the Bali Bombing I (2002), Bali Bombing II (2005), JW Mariot Bomb and Ritz Carlton (2009), Mapolres Bomb Poso (2013), Bom Sarinah (2016) and Kampung Melayu Bomb (2017), are all affiliated with groups that aspire to establish Islamic Sharia in the public constitution, in this case such as the Islamic State of Iraq and Syria (ISIS) (Nisa \& Muchlisin , 2018).

Unclear parameters about the sharia intended in the idealization of the formalization of Islamic law or the Sharia Unitary Republic of Indonesia are likely only to make ideas that will never find a concrete form. The idea is only a mirage that will only lead to violence and terrorism. Plus, the absence of examples/models of countries in the world that have 
implemented Islamic law in a kaffah, is further evidence that the idealization of the formulation of Islamic law is only a burst of religious emotions.

\section{THE ESSENTIAL ISLAMIC STATE OF INDONESIA}

Indonesia has a state foundation, namely, Pancasila. Pancasila itself is not an ideology that is free from ideological debates when it first made. The debate between the founders of the nation in the manufacturing process can not avoid. Muslims at first rejected the state model with the Pancasila ideology because Islamic values were explicitly not seen in the Pancasila formulation. However, in its development, they accept and agree with followers of other religions to be used as the basis of a state capable of covering all differences. Pancasila was not only approved by nationalists but also scholars who did not doubt their knowledge, such as $\mathrm{KH}$ Wahid Hasyim (NU) and also the figure of Ki Bagus Hadikusumo (Muhammadiyah) (Fuad, 2012). According to the writer, it is too hasty in saying that Pancasila is a secular ideology and far from Islam. To say that Pancasila is out of Islamic law is the same as denying the Islamic faith of $\mathrm{KH}$ Wahid Hasyim and Ki Bagus Hadikusumo as the axis of the struggle of Islamic fighters during independence and the formation of the country's foundation. This was also confirmed by Prof. Hamka Al-Haq in his book that Pancasila is truly an embodiment of Islam rahmatal Lil 'âlamin, which can protect the joints of differences within Indonesia, with its people who are able to be friendly, love harmony, tolerance, justice, gender, and equality before the law, as well as being dialogic-constructive (Rohman, 2016).

The Pancasila precepts are in line with Islamic values and do not leave the Islamic domain at all, and are suitable to be confronted with periods in Indonesia (Rohman, 2016). So that in modern times it is unethical to voice the ideology of Islamic Shari'ah when the concrete parameters and examples are still incomplete. If the existence of Pancasila, in addition to being able to shelter the plurality of a nation, be able to respect the nation's ancestors and fighters, and be very thick with Islamic values, then maintaining it is a necessity and even an honor for a great nation (Rohman, 2016). The opinion, it is no exaggeration to say that Pancasila should be affirmed as a contemporary Islamic ideology whose five principles contain high Islamic values, as follows:

The first precepts, the Godhead. This first precept becomes a bastion for anyone in a hurry to implement the Islamic Sharia ideology in total in Indonesia. The concept of Divinity is, of course, the domain of every human being in his life, that is, monothematic God. The use of the first precepts can cover all religions in Indonesia, bearing in mind that Indonesian independence is not base on that all religions are one, but independence is base on God's grace for Indonesia, which consists of people of different faiths. So that this principle of existence can cover all elements of the nation. These first precepts are very close to the word of Allah QS. A1Baqarah: 163, which means: And your Lord is God Almighty; there is no God, but He is the Most Gracious, the Most Merciful. 
The second precepts. Just and Civilized Humanity, this second precept shows that Pancasila requires humans to be fair and polite to one another. If the first precept is related to the relationship between humans and their Lord, then this second precept is the relationship between humans and other humans, this is consistent with QS. Al-Mā'idah: 8, which means: O you who believe, you should be those who always uphold (the truth) because of Allah, be a fair witness. Moreover, do not ever hate hatred towards people, pushing to be unjust. Be fair, because fair is closer to piety. Moreover, fear Allah. Indeed Allah is All-Knowing then us.

The third precept is Indonesian Unity. This third precept wants to say that the Indonesian people in it are closely united. Indonesia stands on the unity of its multicultural citizens. In Islam, the concept of unity is called Ukhuwwah Islāmiyyah (brotherhood of fellow Muslims) and Ukhuwwah Basyariyyah (brotherhood of fellow humans). This third precept is in line with QS. Al-Hujurāt: 10 which means: Believers are indeed brothers. Therefore reconcile (improve the relationship) between your two brothers and fear God so that you may receive mercy.

The fourth precept. Democracy Led by Wisdom Wisdom in Consultation and Representation, this principle gives the intention that Indonesia, with the ideology of Pancasila, prioritizes deliberation in facing the problems of the state or even groups of individuals. With deliberate, it will be easy to find solutions to problems; this is very appropriate for the Koran. Al-Mā'idah: 159 which means: Then it is due to the grace of Allah that you behave gently toward them. If they are hard and hard, they will distance themselves from their surroundings. Therefore forgive them, ask forgiveness for them, and consult with them in the matter. Then when they have made up their mind, but they trust in Allah. Indeed, Allah loves those who put their trust in Him.

The last precept; fifth, namely Social Justice for All Indonesian People, based on these precepts, Pancasila emphasizes the community to uphold justice everywhere in the legal channels. Anyone must be given justice without seeing differences in religion, race, ethnicity, and so on, this is relevant to Islam, which requires its people to be fair to others or themselves. The Koran legalizes justice in the QS. An-Nahl: 90, which means: Verily Allah commands (you) to do justice and do good, give to relatives, and God forbids cruel, evil and hostility. He teaches them so they can take lessons.

The relevance of the five principles of Pancasila, which is the state ideology with the verses of the Koran, is proof that the permanent state of Indonesia, namely Pancasila, is not in the slightest conflict with Islam. Islam and Pancasila can be united in a big vision, namely as a support for security and peace in the land of Indonesia. Islam has been woven intensively in every point of Pancasila, although it is not literal-symbolic. 


\section{NATIONAL VISION OF NKRI}

Vision comes from the Dutch language, which has the meaning of foresight of a community group, institution, or individual on a particular problem (Sumodiningrat, 2015). Soejono's Festschrift stated that the vision of the Indonesian nation was clearly in the struggle for independence, namely the birth of Pancasila. Pancasila became the sole vision of the Indonesian people (Festschift, 2006). So with this, Pancasila can become the vision of the Indonesian nation, which contains five essential things in its five principles, namely divinity, humanity, unity, deliberation, and social justice. The five principles are fundamental to be conceived as a national spill.

Meanwhile, quoting the official website of the Ministry of Foreign Trade, there is a vision of the Indonesian people that must realize in 2020, namely. First, religious, which intended so that the Indonesian people have faith, be cautious following their respective religions. Second, humane; the point is the realization of a society that values human values, does not distinguish between groups. Third, unity; namely by increasing the spirit of unity. Fourth, democratic; which means that there is a balance between the government and the people. Fifth, fair; the enforcement of the law without discrimination by certain parties. Sixth, prosperous. Heading forward. And eighth, independent. The opinion, the vision of the state mentioned above, is essentially relevant to the spirit of Pancasila values in its five principles, which in essence are fighting for the value of religiosity, unity, togetherness, and justice for the Indonesian people.

\section{CELEBRATING SHARIA INDONESIA}

Sharia is a part of Islam. Sharia is not integral to Islam. Islam is a universal vision whose ultimate goal is to give kindness to all people. The religion of Islam not only gives goodness to its adherents but also religious communities outside of Islam. Islamic Sharia, as part of Islam its birth cannot be separated from the historical, social impetus when it was born. Sharia, which is still relevant and useful today, can be implemented today. On the other hand, Shari'a which is already irrelevant and does not provide benefits, does not need to force on, and rejuvenation is needed (Bruinessen, 2002).

If they look at the socio-history, Shari'a is flexible. The Companions of the Prophet strove to produce legal ijtihad that not literally found in the Qur'anic texts or the sayings of the Prophet Muhammad. Two examples that have presented in the previous sub-chapter, regarding the decision of the Caliph 'Umar in making decisions about giving property to people who just converted to Islam and the spoils of war to the soldiers are concrete evidence that the Shari'a is very dynamic. The essence of Shari'a is more prioritized than just the textuality of the sources.

Base on above reality, Indonesia, as a country whose ideology is Pancasila would be appropriate to initiated as a state that is already sharia. Islamic values in the ideology of the nation; Pancasila, in harmony with the 
Islamic values of the country of Medina as the first country in the history of Islam led directly by the Prophet Muhammad, who upholds the values of Islam, namely justice and benefit of mankind at large (Haq, 2015). Every precept of Pancasila, not only has a big vision of providing goodness and benefit to each nation but is also relevant to the values that were conceived by the verses of the Koran. The five essential values of the precepts, namely divinity, humanity, unity, deliberation and social justice, are in harmony with the goal of Islam as a visionary religion of goodness and benefit. Then save this research; Indonesia has been sharia. Its values are relevant to the vision of religion as the mother of sharia, describing the benefit of each nation.

\section{CONCLUSION}

The debate over the issue of Shari'a in the public sphere, which then gave birth to two significant thoughts, namely Fundamentalism and Secularism, could be mediated by Pancasila. With its five precepts that are in harmony with the values of Islam as the axis of the Shari'a, Pancasila is not at a fundamental point, let alone secular. The five principles are Islamic and visionary for the improvement of the individual people of Indonesia. That Pancasila contains the values of Islamic law which are beneficial. As the sole ideology of the Indonesian state, it should say that Indonesia is a sharia country. So that it is not feasible to propagate the Shariah NKRI or the conceptual khilāfah that is conceptual and its parameters are still absurd.

\section{ACKNOWLEDGMENTS}

This scientific article is a study based on existing theories. Therefore the authors would like to thank all authors of books, journals, articles, and all those writers quoted. Hopefully, this will return by Allah. Furthermore, the author would like to thank all the Lecturers and Student friends at STFI Sadra Jakarta and the PTIQ Jakarta Institute, who have deigned to make discussions at every valuable opportunity, so that the writer is provoked to do this research. Moreover, thanks also to Sadra Jakarta STFI Library staff and PTIQ Jakarta for providing the best service in accessing references to this scientific article.

\section{REFERENCES}

Aritonang, Jan S. (2004). Sejarah Perjumpaan Kristen dan Islam di Indonesia, Jakarta: BPK Gunung mulia.

Asrori, Ahmad. (2015). Radikalisme di Indonesia: Antara Historisitas das Antrosipitas, Kalam: Jurnal Agama dan Pemikiran Islam,9(2), 253268.

Bruinessen, Martin Van. (2013). Geneologies of Islamic Radicalism in postSuharto Indonesia, Asian Research,10(2), 117-154.

Bultajiy, Muhammad. (1970). Manhaj Umar Ibn Khattab fi at-Tasyri, Kairo: Dār al-Fikr al-'Arabi.

Celebrating Sharia Indonesia: Islamic Harmony and Pancasila in The Vision of Indonesian Nationality 
Burhanuddin, Nunu. (2016). Akar dan Motif Fundamentalisme Islam: Reformulasi Tipologi Fundamentalisme dan Prospeknya di Indonesia, Wawasan: Jurnal Ilmiah Sosial dan Agama,1(2), 199210.

Fachruddin, Fuad. (2009). Agama dan Pendidikan Demokrasi: Pengalaman Muhammadiyah dan Nahdlatul Ulama. Jakarta: Alvabet.

Fakhruddin, M. Mukhlis. (2011). Muata Nilai dan Prinsip Piagam Madinah dan Pancasila: Analisa Perbandingan, Ulul Albab, 12(1), 96-109.

Fauzia, Amelia. (2013). Faith and The State: A History of Islamic Philanthropy in Indonesia, USA: Brill Press.

Festschrift, Soejono's. (2006). Archeology: Indonesian Perspective. Jakarta: Pustaka Obor.

Fitriono, Eko Nani dan Suhono. (2017). Wacana Negara Islam: Kajian Kritis Konstruksi Pemikiraan Khilafah ala Hizbut Tahrir, Ri'ayah, 2(1), 43-55.

Fuad, Fokky. (2012). Islam dan Ideologi Pancasila: Sebuah Dialektika, Lex Jurnalica,9(3),164-170.

Ghaffar, Muhammad Azizul. (2016). Jihad Fil Pancasila. Yogyakarta: Gharudawaca.

Habbe, dkk. (2012). Pengaruh Rasio Kesehatan Bank Terhadap Kinerja Keungan Bank Umum Syariah dan Konvensional di Indonesia, Analisis, 1(1), 79-86.

Haq, Hamka. (2013). Kandungan Nilai-Nila Syariat Islam Pancasila, Millah,XII(1), 205-2015.

Hidayat, Komaruddin. (2017). Mozaik Keindonesiaan Tercabik, Makalah Komaruddin Hidayat, Seminar Nasional dan Temu Kangen Alumni UMY.

Hiariej, Eric. (2010). Aksi dan Identitas Kolektif Gerakan Islam Radikal di Indonesia, Ilmu Soial Politik, 14(2), 131-168.

JA, Denny. (2019). NKRI Bersyariah atau Ruang Publik yang Manusiawi. Jakarta: Cerah Budaya Indonesia.

Junaid, Hamzah. (2003). Pergerakan Kelompok Terorisme dalam Perspektif Barat dan Timur, Sulesana,8(2), 118-135.

Kafid, Nur. (2015). Ma'had Sebagai Role Model De-Radikalisasi,DINIKA: Journal of Islamic Studies, 13(2) (2015), 22-43.

Kafid, Nur. (2015). Agama Di Tengah Konflik Sosial: Tinjauan Sosiologi atas Potensi Konflik Keberagaman Agama di Masyarakat, AlA'raf:Jurnal Pemikiran Islam dan Filsafat, 12(1), 1- 19.

Khalid, Mahmud. (t.th). Naqd Ad-Dimuqrathi. Beirut: Dār Al-Jail.

Laisa, Emna. (2014). Islam dan Radikalisme, Islamuna, 1(1), 1-19.

Lufaefi, L. (2019). Negara Pancasila: Inspirasi Model Negara Islam Kontemporer Berbasis Tafsir Maqașidi. Jurnal Ilmiah Citra Ilmu, $15(29), 15-27$.

Mustofa, Imam. (2012). Terorisme: Antara Aksi dan Reaksi, Teologia,15(1), 65-87.

Al-Maraghi, Musthafa. (2010).Tafsîr al-Marâghi. Beirut: Dār Ihyā' atTurāt.

Muchlisin, Khairun Nisa dan Ahmad Rolli, Ambivalensi Jihad dan Terorisme, Al-Banjari,17(1), 41-62.

An-Nabhani, Taqiyuddin. (2002). Nizham Al-Hukm. Beirut: Hizbut Tahrir. 
An-Nafi, Bahrul Ulum. (2016). Penormaan dan Karakteristik Prinsip Syari'ah dalam Hukum Nasional Indonesia, penelitian pribadi, dalam bentuk Makalah, 1-23.

An-Na'im, Abdullah Ahmad. (2016). Dekonstruksi Syariah. Yogyakarta: LkiS.

Noor, Iik A. (2009). Revivalism and Radicalism in Southeast Asian Islamic: A Pattern or an Anomaly?,New Zealand of Journal of Asian Studies, 11(1), 222-262.

Rodin, Dede. (2016). Islam dan Radikalisme, ADDIN,10(1), 29-60.

Rohman, Saifullah. (2013). Kandungan Nilai-nilai Islam dalam Pancasila, Millah,XIII(1),207-215.

Romli, Lili. (2004). Partai Islam dan Pemilih Islam di Indonesia, Jurnal Penelitian Politik, 1(1), 29-48.

Ruslan, Idrus. (2013). Membangun Harmonisasi Kehidupan Berbangsa dan Bernegara dengan Nilai Islam pada Pancasila, TAPIs,9(2), 1-21.

Sumodingingrat, Gunawan. (2015). Membangun Dengan Hati. Jakarta: Gramedia.

Tamin, Ar Zaini. (2017). Geneologi Peran Kaum Santri dalam Sketsa Politik Nasional, Al-Ibrah,1(1), 32-59.

Tibbi, Basam. (2016). Islam dan Islamisme. Bandung: Mizan.

Yunus, Nur Rohim. (2015). Penerapan Syariat Islam terhadap Peraturan Daerah dalam Hukum Nasional Indonesia, Hunafa: Jurnal Studi Islamica, 12(2), 253-279.

Zada, Khamani. (2002). Islam Radikal. Jakarta: Teraju.

Zed, Mestika. (2004). Metode Penelitian Kepustakaan. Jakarta: Pustaka Obor.

Zuhdi, Nurdin. (2012). Hermeneutika Al-Qur'an: Tipologi Tafsir Sebagai Solusi Dalam Memecahkan Isu-Isu Budaya Lokal Keindonesiaan, ESENSIA,XIII(2), 211-247. 